\title{
III. 社会の変化と内科学・内科診療
}

\section{1．高辪社会と介護保唤制度 一地域ヶアを担う一診療所からの報告一}

堀川楊堀川 紘三

Key words : 介護保険制度, 在宅医療, サービス利用状況, 医療の変化

\section{1.介護保険までの在宅医療事情}

1965 年に新潟大学脳研究所に神経内科が開設 され，著者（堀川楊）は翌年入局した，疾患の 診断と急性期治療を終えても，重い脳血管障害 や神経変性疾患の患者は退院後の受診もままな らなかった. 1961 年に国民皆保険になってはい たが家族の窓口負担は大きく，長期入院出来る 病院も無く，寝たきりになった患者を出張先の 診療所から往診しても, 裖瘡や排尿障害のある 患者を，医師一人では清潔に保つことさえ困難 であった。医療依存度の高い重度障害患者の診 療システムをどうするかが, 著者にとって生涯 のテーマになった.

1977 年に本邦で初めて慢性人工透析システム を確立した信楽園病院へ赴任し, 翌 1978 年保健 婦 2 名と共に訪問看護と定期往診を提供する継 続医療室を開設した. 1980 年に 65 歳以上人口が $7 \%$ を超え, 日本も高齡化社会に入った. 病院に は一足早く高龄化の波が押し奇せており，リ八

ほりかわよう、ほりかわこうぞう：医療法人朋有会 堀川内科・神経内科医院
ビリテーションを終えて退院する 70〜80 歳代の 脳血管障害患者や神経難病患者の在宅ケアを積 極的に試みたが，当時使える社会資源は障害者 のホームヘルパーのみで, 継続医療室からの訪 問看護は病院からの持ち出しになった。独居患 者も增えていたが，障害が日常生活動作の不自 由に及ぶと彼らの自立を支える事は容易でなく， 毎日ヘルパーが訪問し, 週に 1 回でもどこかの 施設で入浴が出来るような社会の受け血があれ ば施設に送らずに済むのにと，無念に思うこと もしばしばだった。

それでも 1982 年の老人保健法の制定により健 康保険制度に初めて介護を組み入れた特例許可 老人病院の創設を見, 介護力を強化した老人保 健施設の創設(1986 年), 次いで在宅福祉 3 本柱 と言われるホームヘルパー,デイサービス, ショー トステイを制度化した「高齢者保健福祉推進 10 カ年戦略」いわゆる「ゴールドプラン」(1990 年発足)へと発展する。高齢者介護の困難さは, 家族の縮小化もあって現場ではすでに深刻な問 題で, 1990 年の老人福祉法の改正による高齢者 福祉の権限の国から地方自治体への移管と, 民 間委託した老人福祉の相談悹口としての在宅介 


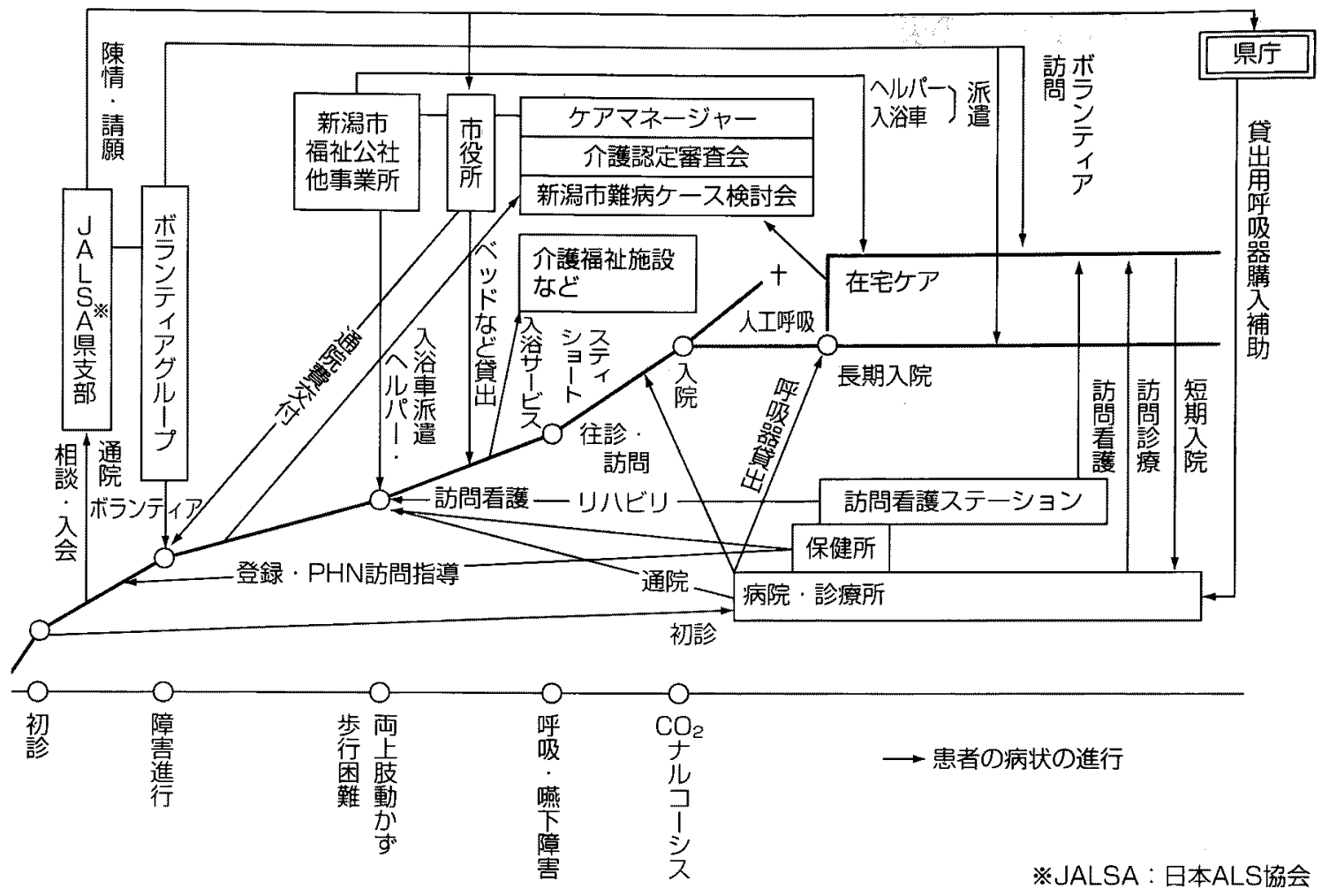

図 . 初診からターミナルまで

一新潟市のALS患者の地域ケアシステム一

護支援センターの創設, 1992 年医療保険で訪問 看護制度を認めた老人訪問看護ステーションの 創設と，次々に創られるサービスは，乾いた砂 に水がしみこむように医療福祉現場に浸透し， 使いこなされていった. 65 歳以上人口が $14 \%$ を 超え高歯社会に突入した 1994 年に, 各種施設人 員の設置到達目標を上方修正するような形で作 られた新ゴールドブランが 1999 年までに目標量 に到達すべく予算措置がとられ，1994 年社会保 障制度審議会で答申以来検討されてきた介護保 険制度が，1997 年「介護保険法」の制定により， 2000 年 4 月にスタートした。

一方, 1988 年から厚生省特定疾患「難病のケ アシステム研究班」では, 筋萎縮性側索硬化症, Parkinson病, 脊䯙小脳変性症など神経難病を始 め特定疾患患者の入院，在宅を含む地域医療， 看護，介護のあり方について，国立療養所を中
心に各地の医療機関の医師，看護師，保健所保 健師など多職種の研究者による横断的な研究が 進められた。これはその後の厚生労働省「特定 疾患患者のQOL (quality of life) の向上に関する 研究班」他の活動入受け継がれ，一連の研究活 動に参加した全国の行政職や病院の医療職の意 識改革に大きく貢献し，各地で具体的な実績を 積み上げた。例えば新潟市に於いては䇨菱縮性 側索硬化症の病状の進展に合わせ,医療サイド, 福祉サイドからの種々のサービスが上手く連携 して図のように提供されるシステムの原型が, 既に 1996 年頃には作られ縦横に用いられていた。 特定疾患地域ケアシステムが高龄者医療福祉提 供システムのモデル足りうることは誰の目にも 明らかで,介護保険の塞質的な受け亚は各地に 育っていたのである. 


\section{2. 介護保険の利用状況と成果一当院にお ける要介護者及び家族のアンケート結 果一}

2000 年 4 月の介護保険制度の発足から 2 年 2 カ月の間に, 著者らが当院で意見書を作成した 患者は 242 名で, 診療対象患者の約 $4.4 \%$ に当た る. 当院は高齢化率も独居または高齢者二人暮 らしの世帯割合も新潟市で最も高い住宅地に, 在宅介護支援センターと訪問看護ステーション を併設して 1997 年に開院した無床診療所(内科 ・ 神経内科）で，居宅介護支援事業所を併設して いる. 意見書を書いた全患者または家族に, 2002 年 7 月介護保険サービスの実際の利用状況, 利 用上の問題点, 介護保険に対する意見等につい てアンケート調査を行った。

調査対象は 242 名で, その内訳は男性 70 名, 女性 172 名, 年齢構成は 40 歳 64 歳が 10 名, 65 歳〜 69 歳が 12 名, 70 歳〜79 歳が 79 名, 80 歳〜89 歳が 120 名, 90 歳以上が 20 名で, 80 藏以上が $58 \%$ を占める。主病名は痴呆 81 名, 神経難病 50 名, 脳血管障害 31 名, 脊柱の老化 による疾患 21 名, 心血管疾患 18 名, 悪性新生 物 10 名, うつ病 10 名, その他糖尿病, 慢性関 節りウマチ，慢性呼吸不全など各数名である.

対象者の要介護認定結果は要支援： 42 人, 17.7 $\%(13.1 \%)$, 要介護 $1: 69$ 人, $29.1 \%(29.3 \%)$, 要介護 $2: 46$ 人, $19.4 \%(18.9 \%)$, 要介護 $3: 33$ 人 $13.9 \%,(13.0 \%)$, 要介護 $4: 13$ 人 $5.5 \%(13.0$ $\%)$, 要介護 $5: 34$ 人 $14.3 \%(12.7 \%)$ で，（）内 の平成 14 年 3 月末の厚生労働省資料による全国 の要支援・要介護者の比率に近似するが, 要支 援と, 要介護 5 の患者の割合がやや高い。ちな みに全国では 280 万人, 全人口の $2.3 \%$ が認定を 受けた. 242 名中 2 年間で 30 名 $(12.4 \%)$ が死亡 し, 在宅で死亡が 10 名 $(33.3 \%)$, 病院で死亡 (長期療盖病棟 2 名を含む) 17 名 $(56.7 \%)$, 施設 で死亡 2 名 $(6.7 \%)$, 徘䧃中の事故死 1 名 (3.3
\%)であった.

介護保険サービスの利用状況を表に示した。 定期的な訪問診療と居宅療養管理指導を 30 名 (18\%) が受け, 訪問看護を 50 名 $(29.9 \%)$ が週 1 から 3 回受けている.訪問介護は最も頻度が高 く66名 $(39.5 \%)$ が利用し, 訪問回数も週 1 2 回が 25 名, 毎日 1 回あるいは 1 日数回の訪問を 受けている患者が 23 名もあった。移動入浴車を 22 名 $(13.2 \%)$ が利用した. 通所系サービスでは 通所介護を 63 名 $(37.7 \%)$ が，通所リハビリを 10 名 $(6 \%)$ が利用し, 短期入所を 34 名（20.4 $\%$ ）が利用していた．短期入所を月に 5 日以上 利用している患者が 21 名あった. 51 名（30.5 \%) がベッド, 車椅子, 歩行器, 杖, リフト等 種々の介護用機器の貸し出しを受けた. 自宅の 段差の解消や手すりの取り付けで住宅改修費用 の補助を 38 名 (22.8\%) が受けた。疾呆対応型 共同生活介護（グループホーム）の入所者が 4 名いる. 表の右列に平成 14 年 1 月審查分の全国 の在宅サービス種類別利用率についての厚生労 働省資料を対比させた．全国平均に比べ居宅療 養指導管理, 訪問看護, 短期入所が多いのは, 往診可能な診療所で訪問看護ステーションを持 ち, 要介護度の高い神経難病患者をケアしてい る特質による. 12 名 $(7.2 \%)$ が介護老人保健施 設に入所し, 2 名が介護老人福祉施設に入所し, 11 名 $(6.6 \%)$ が介護療養型医療施設へ入院した。

介護保険が創設されたことについての患者家 族の感想は, 記入無し 58 名, どちらとも言えな い5 名の外 105 名が「制度の設立はとても良かっ た.ケアマネジャーにもサービス提供事業者か らも良くしてもらっている，老後の安心が大き くなった.介護にかかる経済的負担が軽減した.」 と積極的に評価している．実際利用してみての 問題点として書かれていることは，(1)保険料や 一部負担率の今後の増加が心配. (2)措置制度の 時代より需要が多く,ショートステイやデイサー ビスが使い難い. 施設の増量が急務. (3)書類や 説明書の記載が細かくて分かりにくい。大きい 
表 . 当院要介護者の介護保険サービス利用状況

\begin{tabular}{|c|c|c|c|}
\hline & \multicolumn{2}{|c|}{ 堀川内科・神経内科要介護者 } & \multirow{2}{*}{$\frac{\text { (平成 } 14 \text { 全国調榅 }}{\text { 審査分) }}$} \\
\hline & 利用者数 & 利用率 & \\
\hline 居宅療養管理指導 & 30 名 & $18.0 \%$ & $9.8 \%$ \\
\hline 訪問看護 & 50 & 29.9 & 13.3 \\
\hline 訪問リハビリ & 10 & 6.0 & 1.1 \\
\hline 訪問介護 & 66 & 39.5 & 41.5 \\
\hline 訪問入浴 & 22 & 13.2 & 4.9 \\
\hline 通所介護 & 63 & 37.7 & 38.7 \\
\hline 通所リハビリ & 10 & 6.0 & 20.8 \\
\hline 短期入所 & 34 & 20.4 & 8.6 \\
\hline 福祉用具貸与 & 51 & 30.5 & 27.5 \\
\hline 知呆対応型共同生活介護 & 4 & 2.4 & 0.9 \\
\hline 住宅改修費補助 & 38 & 22.8 & \\
\hline 介護老人保健施設 & 12 & 7.2 & \\
\hline 介護老人福祉施設 & 2 & 1.2 & \\
\hline 介護療養型医療施設 & 11 & 6.6 & \\
\hline
\end{tabular}

字で具体的に分かり易く書いて欲しい. (4)行政 が融通が利かず，諸種の手続きのために介護力 の乏しい家族が，頻回に役所に呼び出されるの が負担. 簡略化して欲しい. (5)独居老人宅での 訪問介護は密室での作業であり，ヘルパーの資 質の向上が必要，などであった，自宅で介護し ている家族への介護料支給の要望, 認定の不公 正などの指摘は 1 例もなかった.

「今後も自宅で過ごしたい, あるいは過ごさせ たいか」の問いには，施設入所を希望する人が 13 名, 出来るだけ最後まで家で過ごしたい，あ るいは家でケアしたい人が 98 名,家にいたいが, 悪化して更に重度の介護が必要になれば，施設 入所もやむを得ないと考えている人が 47 名有り， 現行制度への信頼も窥われた。

\section{3. 介護保険の登場は医療をどう变えつつ あるか}

2002 年現在の 65 嵅以上人口は $17 \%$ を超え, 2025 年には $25 \%$ になる予定で, 年間死亡者数も すでに 100 万人を超えて 2010 年には 130 万人ま で急増すると推計されている。この高齢社会に
於ける医療の主目標は，今まで経験したことの 無い膨大な数の高齢患者に対し，(1)出来るだけ 長く自立した生活が送れるように，きめ細かな 生活指導と医療管理をして良い状態を維持する， (2)病状の悪化時には適切な治療を行い，可及的 速やかに自立生活に戻す，自立困難な場合は適 切な場所で必要な医療・介護を継続的に提供す る，(3)死に至る病を得た人へ尊㧞を保ったター ミナルケアを提供することであろう.

高齢による退行変性や中枢神経系の不可逆的 疾患を持つ高齢者が医療对象の多くを占めると， 急性期疾患が治瘉しても生活障害がもどらない 事も多く, 対象疾患の治癒という従来の目標設 定だけでは対処できなくなる、診断名という座 標軸に加え, 障害の重症度, 社会的環境や心理 状態等, 複数の座標軸の中で患者の全人的な状 態像を把握することで, 病気とそれに基づく機 能障害, それにより生じる生活障害, 社会的不 利益に初めて適切に対応することが出来る.そ の対応の手段として従来の医療保険に加え介護 保険の幅広い併用が可能になった.

介護保険においてサービスを提供する多職種 間の共通言語としてのケースアセスメントの理 
論的根拠は, 英国のマージョリー・ウォーレン の一連の論文に始まると思われるが，彼女は既 に 1940 年代に慢性疾患病棟の老人に対し,伝統 的な医学的問診や診察方法に, ソーシャルワー カーの社会科学的・心理的評価理論を結合させ た，「高齢者総合評価Comprehensive Geriatric Assesment」の方法論を確立して適用し, 高齢者 医療に画期的な成功をおさめた，その導入によ り適切な治療・ケア, 生活の場の選定, 長期的 なフォローアップ, 長期的なケアマネージメン トの為のプランを立てることを可能にしたもの である。

介護保険制度の中で意見書を記入し，認定委 員会に参加し，ケース会議などでケアプラン作 成に関わる事で，既に医師もその共通言語を話 す一職種として，他のサービス事業者や介護支 援専門員と同じ平面に立って患者を支えており， 医師の診断や治療，思考過程が，好むと好まざ るとに関わらず医療機関の密室から，公共の評 価の場に引き出されて来たのだし，これまで余 り注目もしなかった患者の社会的背景にも必然 的に関心を持たざるを得ない状態に押し出され たのである．この医療内容の公開と医師の社会 性の獲得は，介護保険制度がもたらした一つの 大きな利点と思う.

今回のアンケートで，高齡社会の医療に何を 望むかを自由記載方式で問うた。高齢者に分か り易く説明する，地域の主治医は患者，家族の メンタルヘルスケアも含めた全人的なケアをす ベく専門性を磨く, 往診体制の整備, 入退院時 の病診連携, 検查データやフィルムの相互利用, 福祉サービスとの連携も緊密にし経済的, 時間 的無駄を省くままた障害のある患者が入院した 場合，患者が退院したとき再び自立できる事を 目標にして, 生活訓練を病気の治療と並行して 早期から病棟でも行うべきだ，今のような人手 不足の病棟看護では合併症で入院すると退院時 には寝たきりで帰るしかない状況だとの指摘も あった。
介護老人保健施設が，医療機関でありながら 経済的な理由で「ここでは医療を期待しないよ うに」と施設の医師から言われ，Parkinson病治 療薬など高価な薬が使えないとその制度的矛盾 を鋭く突いているものもあった，介護療盖型医 療施設の医療費は幾分か潤沢であるはずだが， ここでも最低限必要な薬剤すら中断されて病状 の悪化を見た患者がいた。病院の入院期間の短 縮と相まって人工呼吸管理, 持続酸素吸入, 経 管栄養, 中心静脈栄盖, 持続導尿などが必要な 医療依存度の高い患者は行くところがない, 最 も重い患者を間欠的な在宅サービスと家族介護 に任せて医師は事たれりとしているのかとの紏 弾もあった。

今回のアンケートで死亡した 30 名中 18 名の 家族から看取り後の感想が寄せられた。在宅死 の患者では往診, 訪問看護, 訪問介護が終末期 にかなり頻回に行われていたことがそれを可能 にしたと感じている家族が多く，全員が大変で はあったが穏やかな死を迎えられて良かったと 評価している。他方病院で死を看取った家族か らは，家ではこれだけの医療を受けさせられな かったと肯定しつつ，管に慗がれた最期がこれ で良かったかと悩む，死戦期にある患者，家族 への心のケアも, 医師, 看護師の仕事の一部と 認識す心゙きとの指摘, 介護療養型医療施設へ移 され医療が手薄の中で死を迎えた事への不満な どが書かれていた。

死ぬまで家にいたいという患者の希望の多さ にも拘わらず，今後更に家族の縮小化が進むこ とを思えば急増する高齢死亡者を看取る場とし ての病院の環境整備は避けられない。施設にも 看取りを受け持たせるので有れば，無理な延命 治療を受けずに自然に死を迎える事も可とする 社会的な合意形成と，ある程度の終末期医療を 提供出来る経済的保証として介護保険上の重症 患者加算が介護老人保健施設, 介護療盖型医療 施設にはぜひ必要である．在宅での死の看取り は，現行の介護保険でのサービスを縦横に用い 
ればかなりな满足度が得られる程度にやれる。

しかし平成 14 年 10 月以後, 診療報酬の大幅な 減収と, 老人医療費の患者負担が 1 2 割と増大 した中で，診療所医師，患者家族の双方が終末 期の在宅医療を何処まで受け入れるか予想しに くい.今後数十年にわたり医療福祉の中心のテー マとなる事が予見できる高齢患者の長期にわた る医療と死の看取りを，日本の医療文化の最大 の遺産である国民皆保険制度と介護保険を守り 育てつつ, 地域の医療福祉関係者が知恵を出し
合って準備することが望まれる。

$$
\text { 文献 }
$$

1）岡本鿆三：高秢者医㙩と福祉. 岩波書店 東京, 1996.

2）堀川 楊：新潟市に於ける在宅医療と今後の問題. 新潟 医学会雑誌 $110 ： 480-486,1996$.

3）平成 12 年版 厚生白書 厚生省 東京, 2000 .

4）栖見英樹：介護保険制度の実施状況，厚生学働省老健局 総務課資料，2002 年 4 月.

5) Warren $\mathrm{MW}$ : Care of the chronic aged sick. Lancet, 1 : 841-843, 1946. 